\title{
Pengaruh Variasi Suhu Pencampuran Dan Pemadatan Agregat Batu Pecah Madura (Desa Asem Jaran Kecamatan Banyuates Kabupaten Sampang) Pada Campuran Aspal Panas (Hotmix) Asphalt Concrete Wearing Course (ACWC), Terhadap Karakteristik Marshall
}

\author{
Taurina Jemmy Irwanto \\ Fakultas Teknik, Universitas Madura, Jl. Raya Panglegur KM. 3,5, Madura, 69371 \\ E-mail: zali@unira.ac.id
}

\begin{abstract}
The mixing temperature has a role in the asphalt smelting process against aggregate, while the compaction temperature has a depth in the density level of the hot asphalt mixture. The better the mixing and compaction process, the better the mixing and compaction process, the better the performance of the asphalt mixture, the better the performance of the asphalt mixture, the better the paved mixture is planned according to the general specifications of Bina Marga 2010. The mixture of mixtures used is Concrete Wearing Course (ACWC). In this study aims to determine the effect of variations in mixing temperature and compaction on the mixture ACWC hot asphalt using broken stone Asem Jaran Distric Banyuates Sampang. Temperature variations used are 160/146 ${ }^{0} \mathrm{C}$, $170 / 156^{\circ} \mathrm{C}, 180 / 166^{\circ} \mathrm{C}, 190 / 176^{\circ} \mathrm{C}$ and $200 / 186^{\circ} \mathrm{C}$ with asphalt content $5,2 \%, 5,7 \%$ dan $6,2 \%$. The test uses the Marshall test method by looking for the charcteristic values of Marshall. Based on the results of testing in the laboratory, it was found an increase in the value of Marshall characteristics from variations in temperature $160 / 146^{\circ} \mathrm{C}$ to $170 / 156^{\circ} \mathrm{C}$ temperature variations and to decrease the test result of Marshall characteristics values at a temperature variation of $180 / 166^{\circ} \mathrm{C}, 190 / 176^{\circ} \mathrm{C}$ and $200 / 186^{\circ} \mathrm{C}$ so that it was concluded that the use of mixing temperature and optimum compaction at a temperature variation of $170 / 156^{\circ} \mathrm{C}$.
\end{abstract}

Keywords—: Temperature; Temperature Variation; Marshall Test; Asphalt concrete Wearing Course (ACWC).

\section{PENDAHULUAN}

Lapis permukaan jalan merupakan lapis perkerasan yang menerima langsung beban lalu lintas. Kekuatan dari campuran untuk lapis permukan jalan sangat tergantung dari agregat dalam campuran itu sendiri baik agregat kasar maupun agregat halus. Agregat merupakan komponen utama dari campuran aspal panas (hotmix) yaitu $\pm 95 \%$ dari total berat campuran .

Kekuatan dan keawetan suatu konstruksi perkerasan jalan sangat tergantung dari kualitas agregat,daya dukung tanah tersebut serta jenis aspal yang digunakan sebagai bahan utama untuk mengikatmaterial-material tersebut hingga didapatkan suatu perkerasan yang awet, tahan lama, kuat dankesat. Dua jenis perkerasan yang biasa digunakan yaitu perkerasan lentur yang menggunakan aspalsebagai bahan pengikatnya dan perkerasan kaku yang menggunakan semen sebagai bahan pengikatagregat. Adapun agregat sebagai komponen utama dari perkerasan jalan raya ini terdiri dari agregatkasar dan agregat halus yang mempunyai proporsi masing-masing sesuai dengan spesifikasi yangdigunakan. Agregat kasar merupakan agregat yang terdiri dari batu pecah atau kerikil pecah yangbersih, kering, kuat, awet, dan bebas dari bahan lain yang akan mengganggu, serta agregat halusmerupakan pasir alam atau pasir buatan yang bebas dari gumpalan-gumpalan lempung danmerupakan butiran yang bersudut tajam dan mempunyai permukaan yang kasar. Agregat kasar berupa batu pecah umumnya didapat dari hasil pemecahan batu-batu berukuran besar oleh alat pemecah batu (Stone Crusher).

Madura merupakan salah satu pulau yang memiliki potensi alam yang sangat besar dimana potensi pertambangan seperti batu pecah yang cukup besar. Batu pecah Madura yang akan diuji adalah batu pecah lokal yang berasal dari Desa Asem Jaran Kecamatan Banyuates Kabupaten Sampang. Dan kondisi yang saat ini dimana perlunya alternatif bahan lain dan harga yang relatif murah, sehingga untuk kontraktor memiliki aternatif aggregat batu pecah ini. Berdasarkan permasalahan diatas penulis melakukan penelitian mengenai pemanfaatan batu pecah madura sebagai agreggat bahan perkerasan jalan raya dengan menggunakan aspal panas jenis AC-WC dengan parameter variasi suhu/tempraturpencampuran dan pemadatan yang berbedabeda.

\section{METODE PENELITIAN}

Penelitian ini menggunakan metode eksprimen. Semua penelitian dilakukan di laboratorium PT. Dua Putri Kedaton dan dengan beberapa percobaan-percobaan. Prosedur penelitian ini dilakukan terhadap agregat dilakukan dengan beberapa pengujian yang dapat mewakili material tersebut dalam pencampuran. Metode pengumpulan data meliputi pengambilan agregat, filler, dan aspal. 
Agregat (material) yang digunakan adalah agregat (material) Madura (Desa Asem Jaran Kecamatan Banyuates Kabupaten Sampang. Jenis material yang diambil adalah agregat kasar (CA), agregat sedang (MA), dan agregat halus (FA). Agregat diambil sebanyak yang diperlukan dalam penelitian. Kemudian dilakukan dengan pengambilan data dari hasil pengujian terhadap kadar aspal yang berbeda dan agregat sesuai dengan spesifikasi gradasi yang berbeda.

B. Filler

Bahan filler yang digunakan adalah Semen Portland (Portlanda Cement/ PC)

C. Aspal

Aspal yang digunakan dalam penelitian ini adalah aspal curah pertamina yang sudah memenuhi spesifikasi penetrasi $60 / 70$ dan layak digunakan padaperencanaanjalan raya, dimana aspal diambil dari AMP PT. Dua Putri Kedaton.

\section{III.HASIL PENELITIAN}

\section{A. Hasil Penelitian}

Hasil penelitian yang dilakukan di Laboratorium Teknik Sipil Fakultas Teknik Universitas Madura terdiri dari hasil pengujian agregat, pengujian aspal dan hasil pengujian dengan metode Marshall untuk campuran beton aspal AC-WC yang mengacu pada Spesifikasi Umum Bina Marga 2010.

Tabel 3.1 Gradasi Agregat untuk campuran aspal beton

\begin{tabular}{|c|c|c|c|c|c|c|}
\hline \multirow{3}{*}{$\begin{array}{c}\text { Ukuran } \\
\text { Ayakan } \\
\text { (mm) }\end{array}$} & \multicolumn{5}{|c|}{$\%$ Berat Yang Lolos terhadap Total Agregat dalam Campuran } \\
\cline { 2 - 7 } & \multicolumn{5}{|c|}{ Laston (AC) } \\
\cline { 2 - 7 } & Gradasi Halus & Base & WC & BC & Base \\
\hline 37,5 & & & 100 & & & 100 \\
\hline 25 & & 100 & $90-100$ & & 100 & $90-100$ \\
\hline 19 & 100 & $90-100$ & $73-90$ & 100 & $90-100$ & $73-90$ \\
\hline 12,5 & $90-100$ & $74-90$ & $61-79$ & $90-100$ & $71-90$ & $55-76$ \\
\hline 9,5 & $72-90$ & $64-82$ & $47-67$ & $72-90$ & $58-80$ & $45-66$ \\
\hline 4,75 & $54-69$ & $47-64$ & $39,5-50$ & $43-63$ & $37-56$ & $28-39,5$ \\
\hline 2,36 & $39,1-53$ & $34,6-49$ & $30,8-37$ & $28-39,1$ & $23-34,6$ & $19-28,6$ \\
\hline 1,18 & $31,6-40$ & $28,3-38$ & $24,1-28$ & $19-25,6$ & $15-22,3$ & $12-18,1$ \\
\hline 0,600 & $23,1-30$ & $20,7-28$ & $17,6-22$ & $13-19,1$ & $10-16,7$ & $7-13,6$ \\
\hline 0,300 & $15,5-22$ & $13,7-20$ & $11,4-16$ & $9-15,5$ & $7-13,7$ & $5-11,4$ \\
\hline 0,150 & $9-15$ & $4-13$ & $4-10$ & $6-13$ & $5-11$ & $4,5-9$ \\
\hline 0,075 & $4-10$ & $4-8$ & $3-6$ & $4-10$ & $4-8$ & $3-7$ \\
\hline
\end{tabular}

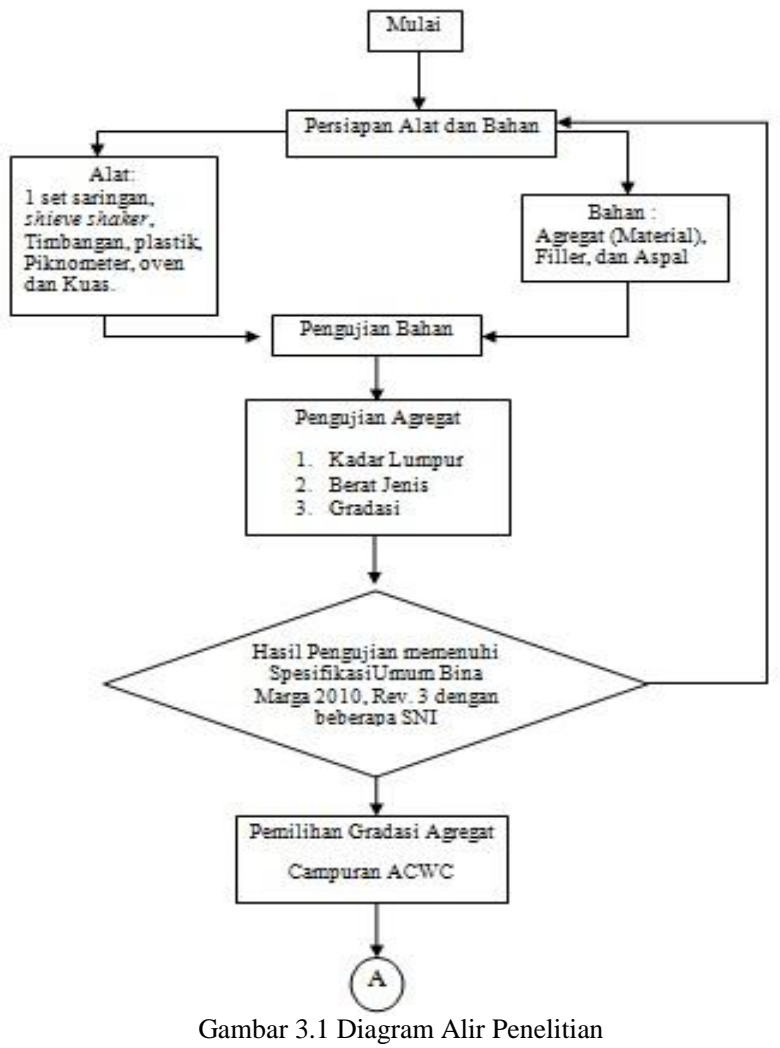

A

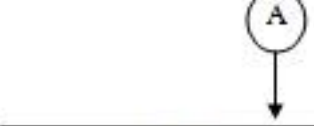

Menentukan Kadar

Aspal Rencana (Kadar aspal optimum $5,7 \%$ ) 
Data dan hasil perhitungan pengujian pada penelitian ini disajikan dalam bentuk tabel, gambar dan grafik untuk dianalisa, hasil pengujiannya adalah sebagai berikut:

\section{B. Hasil Pengujian Agregat}

Hasil pengujian agregat disajikan dalam Tabel 3.2 dan data selengkapnya dapat dilihat pada lampiran-lampiran.

Tabel 3.2 Pengujian Berat Jenis dan Penyerapan Coarse Agregat $(10-15 \mathrm{~mm})$

\begin{tabular}{|c|c|c|c|c|}
\hline \multicolumn{5}{|c|}{ BERAT JENIS DAN PENYERAPAN AGGREGAT } \\
\hline : Coarse Aggregat ( 10 $15 \mathrm{ma}$ ) & \multicolumn{2}{|l|}{ A } & \multirow[b]{2}{*}{ 】 } & \multirow[b]{2}{*}{ Average } \\
\hline NO. Contoh & & $\mathbf{I}$ & & \\
\hline Berat benda uj kering oven & A & 1710 & 1663 & \\
\hline Berat benca uj datam kering permukaan & B & 1725 & 1698 & \\
\hline Berat benca uj kering permukaan jenuh datamair & c & 1128 & 1108 & \\
\hline \multirow{2}{*}{ Berat Jenis ( oven dy) } & A & 2,864 & 2,819 & \\
\hline & $\overline{B-C}$ & Average & & 2,841 \\
\hline \multirow{2}{*}{$\begin{array}{l}\text { Berat jenis kering permukaan jemu ( saturated } \\
\text { surface dry) }\end{array}$} & B & 2,889 & 2,878 & \\
\hline & $\overline{B-C}$ & Average & & 2,884 \\
\hline \multirow{2}{*}{ Berat jenis semu (Apparent Specific Gravity) } & $A$ & 2,938 & 2,996 & \\
\hline & $\overline{A-C}$ & Average & & 2,967 \\
\hline \multirow{2}{*}{ Penyerapan (Absorbsi) \% } & $\underline{(B-A)} \times 100$ & 0,877 & 2,105 & \\
\hline & & Average & & 1,491 \\
\hline
\end{tabular}

Tabel 3.3. Pengujian Berat Jenis dan Penyerapan Medium Agregat $(05-10 \mathrm{~mm})$

\begin{tabular}{|c|c|c|c|c|c|c|c|}
\hline \multicolumn{7}{|c|}{ BERAT JENIS DAN PENYERAPAN AGGREGAT } & \multirow{3}{*}{ 19, PILAR TEKNOLOGI | 8} \\
\hline $\begin{array}{l}\text { Tanggal } \\
\text { Jenis Material }\end{array}$ & $\begin{array}{l}\text { : } \\
\text { : Wedian Agghegat ( } 05 \text { } 1\end{array}$ & & \multicolumn{4}{|c|}{ Volume 4 Nomor 1 Maret 20} & \\
\hline \multicolumn{3}{|c|}{ NO. Contoh } & & $\mathbf{I}$ & प & Average & \\
\hline \multicolumn{2}{|c|}{ Berat benda uj kering oven } & (gr) & $\mathbf{A}$ & 1507 & 1514 & & \\
\hline \multicolumn{2}{|c|}{ Berat benda uj datam kering permukaan } & (gr) & B & 1524 & 1530 & & \\
\hline \multicolumn{2}{|c|}{ Berat benda uj kering permukaan jenuh datamair } & (gr) & $\mathbf{C}$ & 924 & 946 & & \\
\hline
\end{tabular}


Tabel 3.4. Pengujian Berat Jenis dan Penyerapan Fine Agregat $(00-05 \mathrm{~mm})$

\begin{tabular}{|c|c|c|c|c|}
\hline \multicolumn{5}{|c|}{ BERAT JENIS DAN PENYERAPAN AGGREGAT } \\
\hline \multicolumn{5}{|l|}{;Fre Acoreant $(00$ 05 on) } \\
\hline :Fne Aggregat ( 00 05 m ) & A & & & \\
\hline NO. Contoh & & $\mathbf{I}$ & प & Average \\
\hline Berat benda uj kering oven & 500 & & & \\
\hline Berat benda uj datam kering permukaan & A & 490,9 & 491,9 & \\
\hline Berat piknometer + air & B & 716,9 & 720,1 & \\
\hline Berat piknometer + Contoh + air & c & 1035,3 & 1036,1 & \\
\hline \multirow{2}{*}{ Berat Jenis ( oven dy ) } & A & 2,703 & 2,673 & \\
\hline & $(\mathrm{B}+500 \mathrm{C})$ & Average & & 2,688 \\
\hline \multirow{2}{*}{$\begin{array}{l}\text { Berat jenis kering permukaan jemu ( saturated } \\
\text { surface dry ) }\end{array}$} & 500 & 2,753 & 2,717 & \\
\hline & $(\mathrm{B}+500 \mathrm{C})$ & Average & & $\mathbf{2 , 7 3 5}$ \\
\hline \multirow{2}{*}{ Berat jenis semu (Apparent Specific Gravity) } & A & 2,846 & 2,796 & \\
\hline & $(B+A C)$ & Average & & 2,821 \\
\hline \multirow{2}{*}{ Penyerapan (Absorbsi) \% } & $(500-A) \times 100$ & 1,854 & 1,647 & \\
\hline & A & Average & & 1,750 \\
\hline
\end{tabular}

\section{Pemilihan Gradasi Agregat Campuran}

Setelah melakukan pengujian masing-masing agregat selanjutnya melakukan gradasi (analisa saringan) untuk mengetahui apakah gradasi agregat campuran memenuhi syarat atau tidak memenuhi syarat.

Tabel 3.5 Analisa SaringanCoarse Agregat $(10-15 \mathrm{~mm})$

\begin{tabular}{|c|c|c|c|c|c|c|c|c|}
\hline \multicolumn{9}{|c|}{ Gradasi Agregat } \\
\hline \multirow{2}{*}{\multicolumn{2}{|c|}{$\begin{array}{l}\text { Tanggal } \\
\text { Jeris Material } \\
\text { Total Material }\end{array}$}} & \multicolumn{7}{|c|}{$\begin{array}{l}: \\
: \text { CoarseAggregte }(10 \sim 15 \mathrm{~m})\end{array}$} \\
\hline & & \multirow{2}{*}{\multicolumn{2}{|c|}{$\begin{array}{c}3645 \quad \text { Gram } \\
\text { KUUATIF }\end{array}$}} & \multicolumn{2}{|c|}{ Total Material } & \multicolumn{2}{|c|}{3572 Gram } & \\
\hline \multirow{2}{*}{$\begin{array}{l}\text { SEVE } \\
\text { SRE }\end{array}$} & & & & \multirow{2}{*}{$\begin{array}{l}\text { SEVE } \\
\text { SEIE }\end{array}$} & \multicolumn{3}{|c|}{ KUUATIF } & \multirow{2}{*}{ Rta-Rta } \\
\hline & B. Tethenan & \% Tetathan & KLohs & & B. Terthan & \% Tettanan & \%Ldos & \\
\hline $12^{n}$ & 1250,0 & 34,29 & 65,71 & $1 / 2^{n}$ & 1140,0 & 31,91 & 68,09 & 66,90 \\
\hline $38^{n}$ & 3431,0 & 94,13 & 5,87 & $3 / 8 "$ & 3356,0 & 93,95 & 6,05 & 5,96 \\
\hline \#4. & 3550,0 & 97,39 & 2,61 & $\# 4$ & 34720 & 97,20 & 280 & 270 \\
\hline$\# 8$. & 3596,0 & 98,66 & 1,34 & $\# 8$ & 35190 & 98,52 & 1,48 & 1,41 \\
\hline$\# 16$. & 3634,0 & 99,70 & 0,30 & $\# 16$. & 3553,0 & 99,47 & 0,53 & 0,42 \\
\hline$\$ 30$. & 3640,0 & 99,86 & 0,14 & $\# 30$ & 3567,0 & 99,86 & 0,14 & 0,14 \\
\hline
\end{tabular}

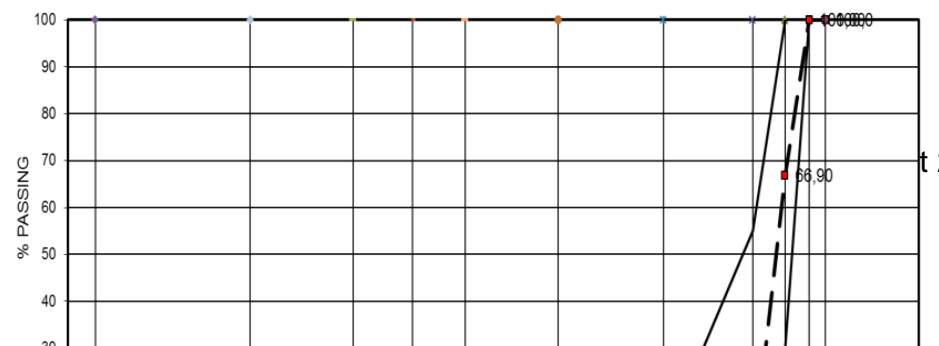


Tabel 3.6. Analisa SaringanMedium Agregat (05 - $10 \mathrm{~mm})$

\begin{tabular}{|c|c|c|c|c|c|c|c|c|}
\hline \multicolumn{9}{|c|}{ Gradasi Agregat } \\
\hline \multirow{2}{*}{\multicolumn{2}{|c|}{$\begin{array}{l}\text { Tanggal } \\
\text { Jenis Material } \\
\text { Total Material }\end{array}$}} & \multicolumn{7}{|c|}{$\begin{array}{l}: \\
: \text { Uled W Aggregate( } 05 \sim 10 \mathrm{~m} \text { ) }\end{array}$} \\
\hline & & \multirow{2}{*}{\multicolumn{2}{|c|}{$\begin{array}{l}2763,0 \text { Gram } \\
\text { KWUATIF }\end{array}$}} & \multicolumn{2}{|c|}{ Total Material } & \multicolumn{2}{|c|}{2143 Gram } & \multirow{3}{*}{ Reth-Rte } \\
\hline \multirow{2}{*}{$\begin{array}{l}\text { SEVE } \\
\text { SIII } \\
\end{array}$} & & & & \multirow{2}{*}{$\begin{array}{l}\text { SEVE } \\
\text { SRE }\end{array}$} & \multicolumn{3}{|c|}{ KUUATIF } & \\
\hline & B. Tertanan & \% Tetathan & \%Lolos & & B. Tethan & \% Tetthen & \%Lolos & \\
\hline $3 / 8^{n}$ & 35,70 & 1,29 & 98,71 & $3 / 8^{n}$ & 39,4 & 1,84 & 98,16 & 98,43 \\
\hline$\# 4$. & 1529,0 & 55,34 & 44,66 & $\# 4$ & 1338 & 6244 & 37,56 & 41,11 \\
\hline$\# 8$. & 2376,3 & 86,00 & 14,00 & \#8. & 1868,4 & 87,19 & 1281 & 13,40 \\
\hline$\# 16$ & 2568,2 & 9295 & 7,05 & $\# 16$. & 20428 & 95,32 & 4,68 & 5,86 \\
\hline$\# 30$. & 2720,0 & 98,44 & 1,56 & $\# 30$. & 2117,2 & 98,80 & 1,20 & 1,38 \\
\hline$\# 50$. & 2755,0 & 99,71 & 0,29 & $\# 50$. & 2137,8 & 99,76 & 0,24 & 0,27 \\
\hline
\end{tabular}

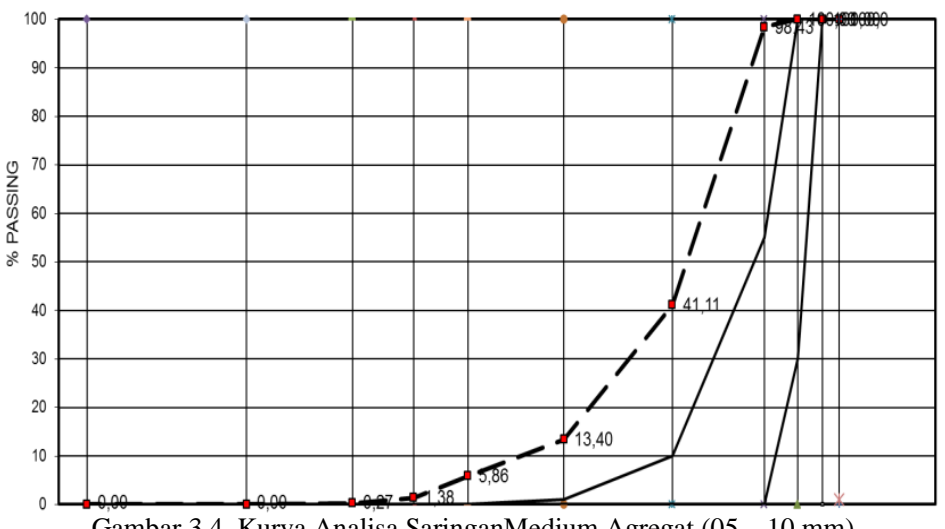

Gambar 3.4 Kurva Analisa SaringanMedium Agregat (05 - $10 \mathrm{~mm})$

Tabel 3.7. Analisa SaringanFine Agregat $(00-05 \mathrm{~mm})$

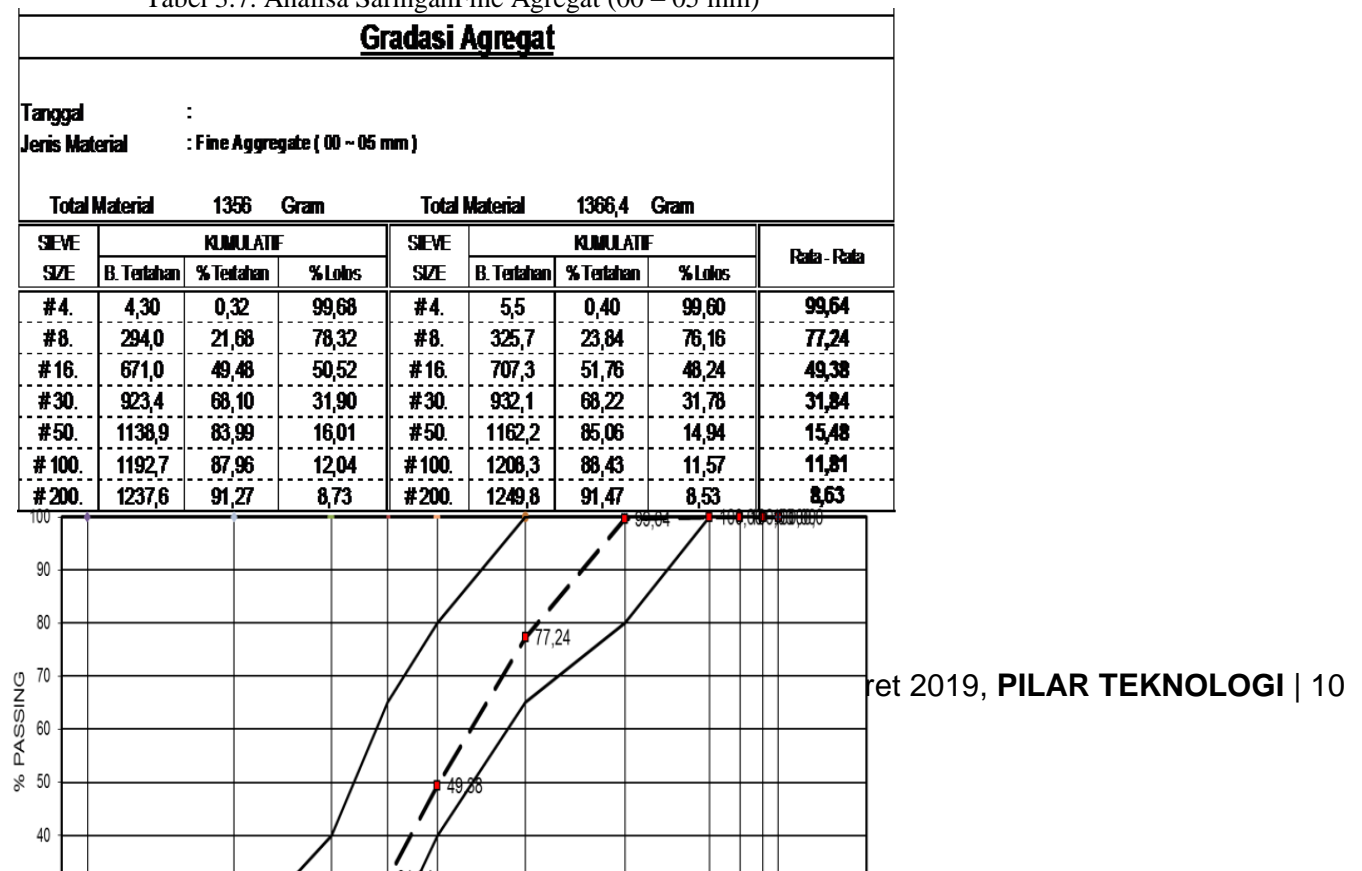




\section{Ketentuan Agregat}

Untuk memenuhi nilai maksimum dan minimum suatu agregat maka ada batasan dimana batasan tersebut sudah tercantum dibeberapa spesifikasi yang ada di Indonesia maupun di dunia, berdasarkan Departemen Pekerjaan Umum 2010.

\begin{tabular}{|l|l|l|}
\hline \multicolumn{1}{|c|}{ Pengujian } & \multicolumn{1}{c|}{ Standar } & Nilai \\
\hline Abrasi dengan mesin Los Angeles & SNI 03-2417-1991 & Maks.40\% \\
\hline Partikel pipih dan lonjong $\left(^{* *}\right)$ & RSNI T-01-2005 & Maks.10\% \\
\hline
\end{tabular}

Tabel 3.8 Daftar Gradasi dan Berat Benda Uji

\begin{tabular}{|c|c|c|c|c|c|c|c|c|c|c|}
\hline \multicolumn{4}{|c|}{ Ukuran saringan } & \multicolumn{7}{|c|}{ Gradasi dan berat benda uji ( gram) } \\
\hline \multicolumn{2}{|c|}{ Lolos saringan } & \multicolumn{2}{|c|}{ Tertahan saringan } & \multirow[b]{2}{*}{ A } & \multirow[b]{2}{*}{ B } & \multirow[b]{2}{*}{$c$} & \multirow[b]{2}{*}{ D } & \multirow[b]{2}{*}{ E } & \multirow[b]{2}{*}{$F$} & \multirow[b]{2}{*}{ G } \\
\hline $\mathrm{mm}$ & inci & $\mathrm{mm}$ & inci & & & & & & & \\
\hline 75 & 3 & 63 & $21 / 2$ & - & - & - & - & $2500 \pm 50$ & - & - \\
\hline 63 & $21 / 2$ & 50 & 2 & - & - & - & - & \begin{tabular}{|c}
$2500 \pm$ \\
50
\end{tabular} & - & - \\
\hline 50 & 2 & 37,5 & $11 / 2$ & - & - & - & - & $\begin{array}{c}5000 \pm \\
50\end{array}$ & $\begin{array}{c}5000 \pm \\
50\end{array}$ & - \\
\hline 37,5 & $11-\mathrm{Feb}$ & 25 & 1 & $\begin{array}{c}1250 \pm \\
25\end{array}$ & - & - & --- & - & \begin{tabular}{|c|}
$5000 \pm$ \\
25 \\
\end{tabular} & $\begin{array}{c}5000 \pm \\
25 \\
\end{array}$ \\
\hline 25 & 1 & 19 & 03-Apr & $1250 \pm 25$ & - & - & - & - & - & $\begin{array}{c}5000 \pm \\
25\end{array}$ \\
\hline 19 & 03-Apr & 12,5 & 01-Feb & $1250 \pm 10$ & $2500 \pm 10$ & - & - & - & - & - \\
\hline 12,5 & 01-Feb & 9,5 & 03-Agust & $1250 \pm 10$ & $2500 \pm 10$ & - & - & - & - & - \\
\hline 9,5 & 03-Agust & 6,3 & $1 / 4$ & - & - & $2500 \pm 10$ & - & - & - & - \\
\hline 6,3 & 01-Apr & 4,75 & No.4 & - & - & $2500 \pm 10$ & $2500 \pm 10$ & - & - & - \\
\hline 4,75 & No. 4 & 2,36 & No. 8 & - & - & - & $2500 \pm 10$ & - & - & - \\
\hline \multicolumn{4}{|c|}{ Total } & $5000 \pm 10$ & $5000 \pm 10$ & $5000 \pm 10$ & $5000 \pm 10$ & $\begin{array}{c}10000 \pm 1 \\
0\end{array}$ & $\begin{array}{c}10000 \pm 1 \\
0\end{array}$ & $\begin{array}{c}10000 \pm 1 \\
0\end{array}$ \\
\hline \multicolumn{4}{|c|}{ Jumlah bola } & 12 & 11 & 8 & 6 & 12 & 12 & 12 \\
\hline \multicolumn{4}{|c|}{ Berat bola (gram) } & $5000 \pm 25$ & $4584 \pm 25$ & $3330 \pm 20$ & $2500 \pm 15$ & $5000 \pm 25$ & $5000 \pm 25$ & $5000 \pm 25$ \\
\hline
\end{tabular}

E. Kombinasi Agregat Campuran

\begin{tabular}{|c|c|c|}
\hline \multicolumn{2}{|c|}{ Gradasi pemeriksaan } & $\begin{array}{c}\text { Jumlah putaran }= \\
500 \text { putaran }\end{array}$ \\
\hline \multicolumn{2}{|c|}{ Ukuran saringan } & $\mathbf{I}$ \\
\hline Lolos & Tertahan & Berat (a) \\
\hline 76,2 (3") & 63,5 (2 1/2"') & \\
\hline $63,5\left(2^{1 / 2 "}\right)$ & $50,8\left(2^{\prime \prime}\right)$ & \\
\hline $50,8(2 ")$ & $36,1\left(11^{1 / 2}\right)$ & \\
\hline $36,1\left(1^{1 / 22^{\circ}}\right)$ & $25,4\left(1^{\prime \prime}\right)$ & \\
\hline $25,4(1 ")$ & $19,1\left(3 / 4^{\prime \prime}\right)$ & \\
\hline $19,1(3 / 4 ")$ & $12,7(1 / 2 ")$ & 2500 \\
\hline $12,7(1 / 2 ")$ & $9,52\left(3 / 8^{\prime \prime}\right)$ & 2500 \\
\hline $9,52\left(3 / 8^{\prime \prime}\right)$ & $6,35\left(1 / 4^{\prime \prime}\right)$ & \\
\hline $6,35(1 / 4 ")$ & 4,75 (No. 4) & \\
\hline 4,75 (No. 4) & 2,36 (No. 8) & \\
\hline \multicolumn{2}{|c|}{ Jumlah Berat } & 5000 \\
\hline \multicolumn{2}{|c|}{$\begin{array}{c}\text { Berat tertahan saringan No. } 12 \\
\text { sesudah }\end{array}$} & \multirow[t]{2}{*}{3752} \\
\hline perc & $\operatorname{aan}(\mathrm{b})$ & \\
\hline
\end{tabular}


PILAR TEKNOLOGI : Jurnal IImiah IImu-IImu Teknik

Website : http://pilar.unmermadiun.ac.id/index.php/pilarteknologi

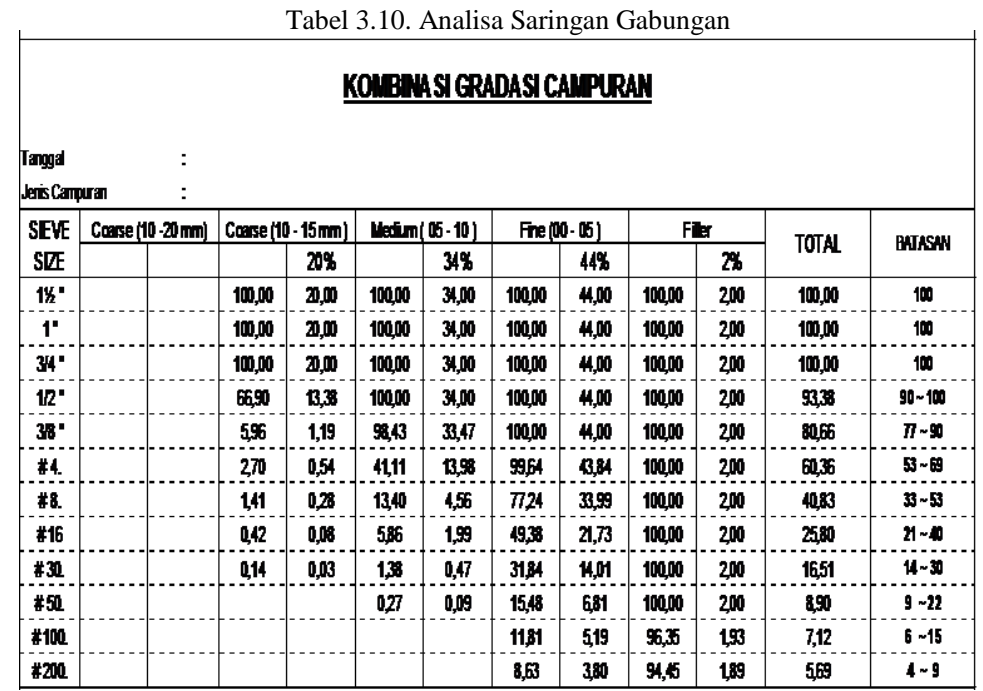

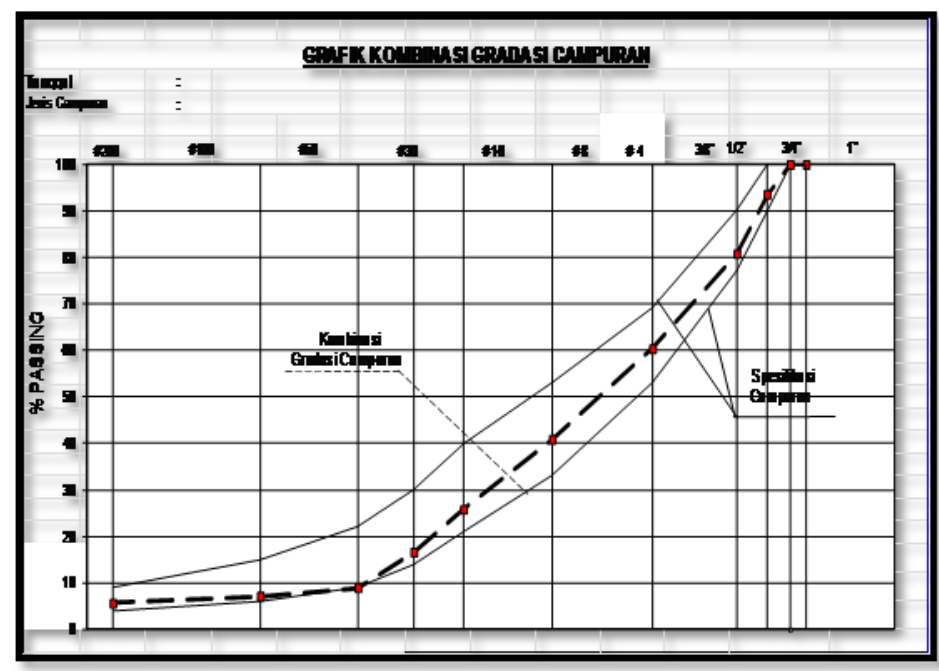

Gambar 3.6 Kurva Analisa Saringan Gabungan

\section{F. Perhitungan Marshall Berbagai Variasi suhu.}

1. Variasi suhu I, Suhu Pencampuran $160^{\circ} \mathrm{C}$, Suhu Pemadatan $146^{\circ} \mathrm{C}$.

2. Variasi suhu II, Suhu Pencampuran $170^{\circ} \mathrm{C}$, Suhu Pemadatan $156^{\circ} \mathrm{C}$.

3. Variasi suhu III, Suhu Pencampuran $180^{\circ} \mathrm{C}$, Suhu Pemadatan $166^{\circ} \mathrm{C}$.

4. Variasi suhu IV, Suhu Pencampuran $190^{\circ} \mathrm{C}$, Suhu Pemadatan $176^{\circ} \mathrm{C}$

5. Variasi suhu V, Suhu Pencampuran $200^{\circ} \mathrm{C}$, Suhu Pemadatan $186^{\circ} \mathrm{C}$.

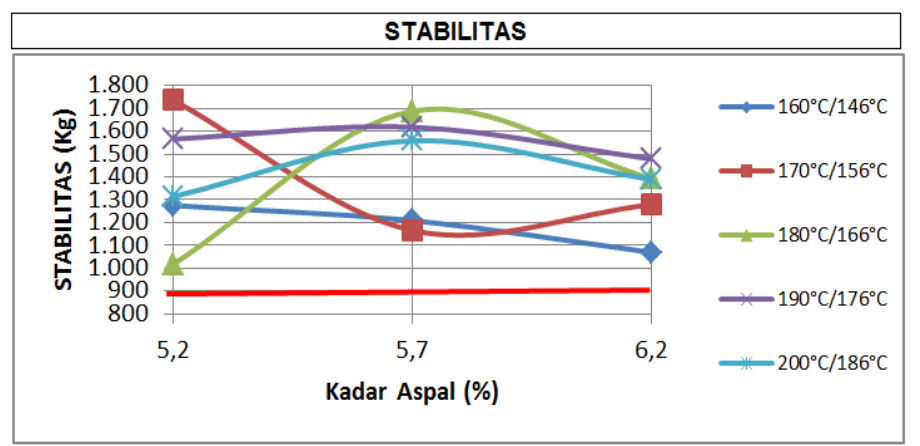

Gambar 3.7 Kurva HubunganStabilitas dan Kadar Aspal dengan variasi suhu pencampuran dan pemadatan

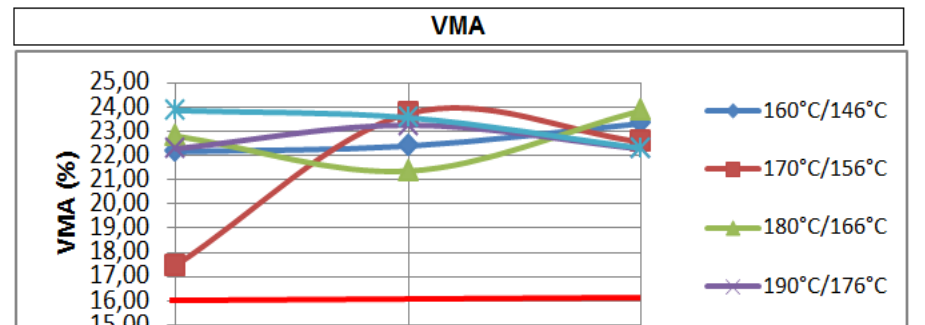




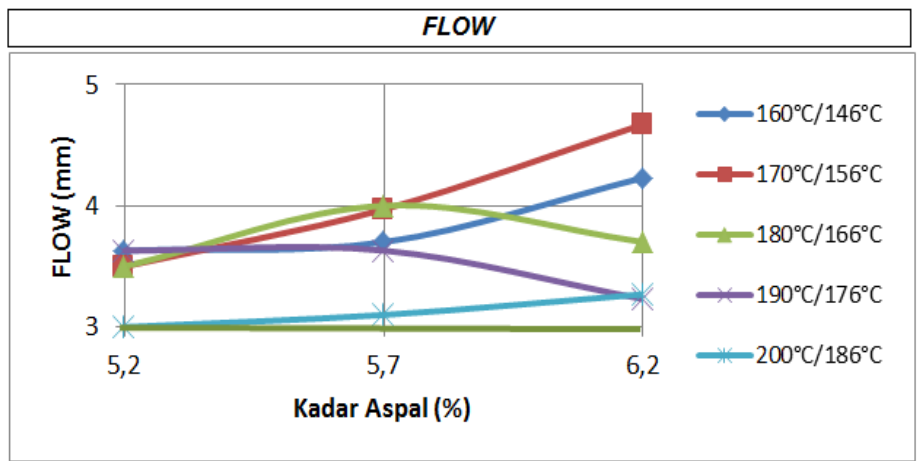

Gambar 3.9 Kurva Hubungan Flow dan Kadar Aspal dengan Variasi Suhu Pencampuran dan Pemadatan

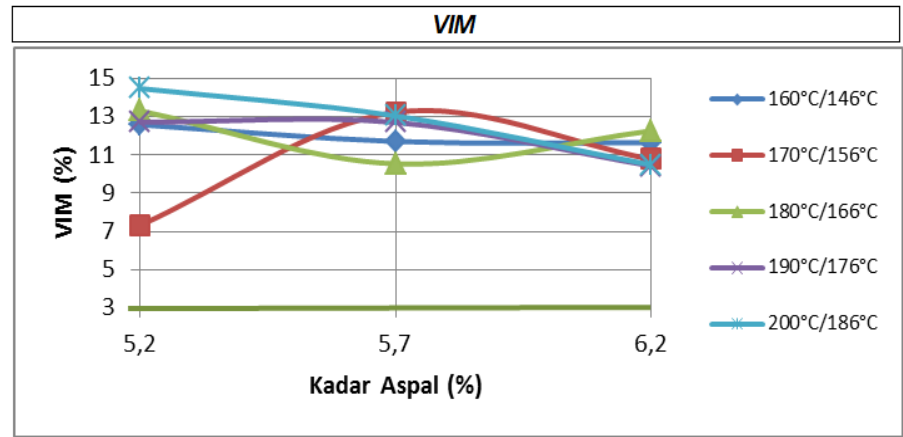

Gambar 4.8 Kurva HubunganVIM dan Kadar Aspal dengan Variasi Suhu Pencampuran dan Pemadatan

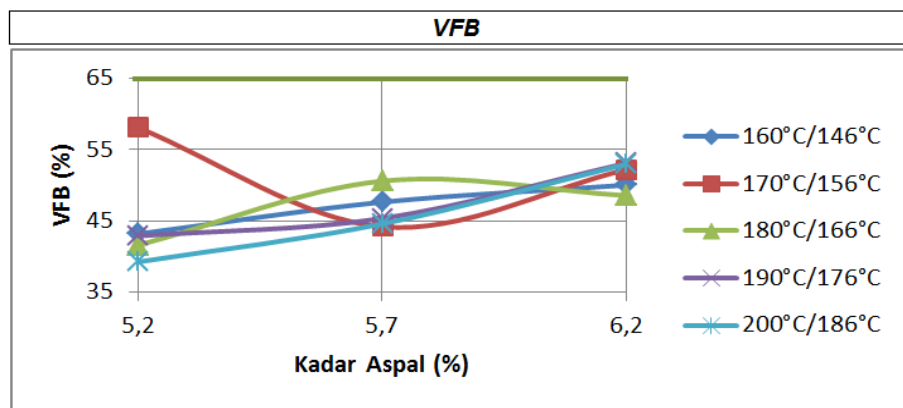

Gambar 4.9 Kurva Hubungan VFB dan Kadar Aspaldengan Variasi Suhu Pencampuran dan Pemadatan

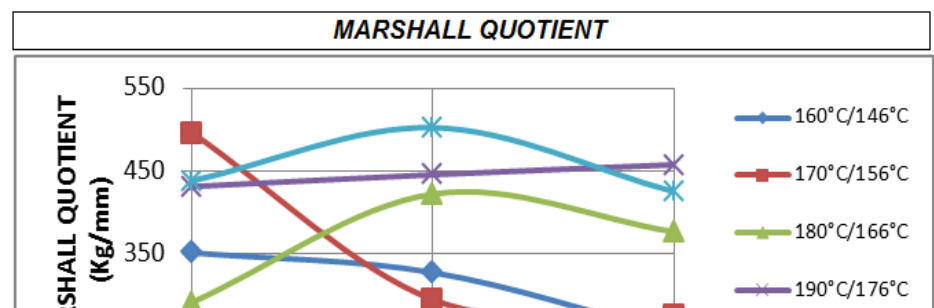




\section{IV.KESIMPULAN}

Setelah dilakukan pengujian analisa saringan pada agregat batu pecah Desa Asem Jaran Kecamatan Banyuates Kabupaten Sampang dapat memenuhi syarat sesuai spesifikasi Bina Marga 2010 Revisi 3 dan dapat digunakan pada pembuatan aspal panas ACWC dengan parameter marshall.

Dari hasil pengujian marshall, maka dapat disimpulkan variasi suhu pencampuran dan pemadatan dari $160 / 146^{\circ} \mathrm{C}$, $170 / 156^{\circ} \mathrm{C}, 180 / 166^{\circ} \mathrm{C}, 190 / 176^{\circ} \mathrm{C}$, dan $200 / 186^{\circ} \mathrm{C}$ sangat berpengaruh terhadap hasil uji yang ditunjukkan dengan peningkatan sampai dengan penuruan hasil uji dari setiap variasi suhu pencampuran dan pemadatan.

Berdasarkan hasil pengujian juga disimpulkan bahwa variasi suhu yang layak digunakan pada suhu pencampuran dan pemadatan $170 / 156^{\circ} \mathrm{C}$ dengan variasi aspal $5,20 \%$ berdasarkan hasil uji marshall dengan karaktersitik marshall hampir memenuhi semua klasifikasi yaitu satabilitas sebesar $1736 \mathrm{Kg}$, flow denga hasil 3,5 mm, masrshall quotient dengan nilai 495,98 Kg/mm serta VMA sebesar 17,46 \%, sedangkan pada VIM dan VFB belum memenuhi klasifikasi yaitu untuk VIM sebesar 7,32\% yang seharusnya menurut klasifikasi harus bernilai 3-5\% dan VFB sebesar 44,17\% dan menurut klasifikasi harus $>65 \%$. Namun dari semua variasi suhu, pada suhu pencampuran dan pemadatan $170 / 156^{\circ} \mathrm{C}$ nilai VIM dan VFB yang paling mendekati kalsifikasi diantara variasi suhu yang lainnya.

\section{DAFTAR PUSTAKA}

Harianto R., 2017, Sistem Informasi Ketersediaan Stok Handphone Menggunakan Metode Double Exponential Smoothing (Studi kasus di Edyta Cell), Universitas Nusantara PGRI, Kediri

Kusnianti, Neni (2009). "Modul Pengambilan Contoh dan Pengujian Agregat untuk Pekerjaan Campuran Beraspal”. Puslitbang Jalan dan Jembatan: Bandung. Kementrian Pekerjaan Umum (2010). "Spesifikasi Umum Bina Marga Revisi 3".Yayasan Penerbit Pekerjaan Umum: Jakarta.

Leo Sentosa,ST. MT, Yosi Alwinda, ST.MT, Elianora dan Joko Susilo (2013). "Pengaruh Variasi suhu pencampuran dan pemadatan campuran beraspal panas menggunakan aspal retona blend 55". Fakultas Teknik Universitas Riau.

Pangemanan, VC, Kaseke, OH dan Manoppo, MRE (2015). “ Pengaruh suhu dan durasi terendamnya perkerasan beraspal panas terhadap stabilitas dan kelelehan (flow). Jurnal sipil statik vol.3 no. 2, februari 2015 (85-90) ISSN:2337-5732.

Raharjo, B, Ali, H, dan Pratomo, P (2016). "Pengaruh suhu tumbukan pada campuran aspal beton dengan jenis lapis AC-WC dengan gradasi halus untuk perkerasan lapis antara (AC-BC). JRSDD, Edisi Juni 2015, vol. 3, no. 2, 351-360 (ISSN:2303-0011).

Raharjo, B, Ali, H, dan Pratomo, P (2016). “Pengaruh suhu pemadatan campuran untuk perkerasan lapis antara (AC-BC). JRSDD, Edisi maret 2016, vol. 4, hal. 43-50 (ISSN:2303-0011).

Sukirman, Silvia. 2003. "Beton Aspal Campuran Panas”. Granit:Jakarta.

Yulianto, FE dan Mukti, MH (2015). "Penggunaan abu sekam padi sebagai bahan aditif pada beton campuran 1Pc:2Ps:3Kr untuk meningkatkan kuat tekannya". Universitas Madura, Pamekasan. 